\title{
A Novel G $\beta \gamma$-Subunit Inhibitor Selectively Modulates $\mu$-Opioid-Dependent Antinociception and Attenuates Acute Morphine-Induced Antinociceptive Tolerance and Dependence
}

\author{
Jennifer L. Mathews, Alan V. Smrcka, and Jean M. Bidlack \\ Department of Pharmacology and Physiology, University of Rochester, School of Medicine and Dentistry, Rochester, New York $14642-8711$
}

\begin{abstract}
The $\mathrm{G} \beta \gamma$ subunit has been implicated in many downstream signaling events associated with opioids. We previously demonstrated that a small molecule inhibitor of $\mathrm{G} \beta \gamma$-subunit-dependent phospholipase (PLC) activation potentiated morphine-induced analgesia (Bonacci et al., 2006). Here, we demonstrate that this inhibitor, M119 (cyclohexanecarboxylic acid [2-(4,5,6-trihydroxy-3-oxo-3H-xanthen-9-yl)$(9 \mathrm{Cl})]$ ), is selective for $\mu$-opioid receptor-dependent analgesia and has additional efficacy in mouse models of acute tolerance and dependence. When administered by an intracerebroventricular injection in mice, M119 caused 10-fold and sevenfold increases in the potencies of morphine and the $\mu$-selective peptide, DAMGO, respectively. M119 had little or no effect on analgesia induced by the $\kappa$ agonist U50,488 or $\delta$ agonists DPDPE or Deltorphin II. Similar results were obtained in vitro, as only activation of the $\mu$-opioid receptor stimulated PLC activation, whereas no effect was seen with the $\kappa$ - and $\delta$-opioid receptors. M119 inhibited $\mu$-receptor-dependent PLC activation. In studies to further explore the in vivo efficacy of M119, systemic administration M119 also resulted in a fourfold shift increase in potency of systemically administered morphine. Of particular interest, M119 was also able to attenuate acute, antinociceptive tolerance and dependence in mice treated concomitantly with both M119 and morphine. These studies suggest that small organic molecules, such as M119, that specifically regulate G $\beta \gamma$ subunit signaling may have important therapeutic applications in enhancing opioid analgesia, while attenuating the development of tolerance and dependence.
\end{abstract}

Key words: opioid; $\mathrm{G} \beta \gamma$-subunit; tolerance; dependence; antinociception; mice

\section{Introduction}

Opioid analgesics are clinically important for the treatment of moderate to severe pain. The three types of opioid receptor, $\mu, \delta$, and $\kappa$, are G-protein-coupled receptors that activate $\mathrm{G}_{\mathrm{i}}$, resulting in inhibition of adenylyl cyclase activity (Sharma et al., 1977), activation of inwardly rectifying $\mathrm{K}^{+}$channels (North et al., 1987), inhibition of voltage-activated $\mathrm{Ca}^{2+}$ channels (Moises et al., 1994), and the activation of mitogen-activated protein kinase, extracellular signal-regulated ERK-1/2 kinases (Law et al., 2004), and phosphatidylinositol (PI)-specific phospholipase C (PLC) (Xie et al., 1999). Recently, the importance of $\mathrm{G} \beta \gamma$-mediated activation of PI-PLC in the potentiation of opioid analgesia has been examined (Xie et al., 1999; Galeotti et al., 2006).

\section{Received May 9, 2008; revised Sept. 17, 2008; accepted 0ct. 6, 2008}

This work was supported by National Institutes of Health (NIH) Grants K05-DA00360 (J.M.B.), GM60286 (A.V.S.), and National Institute on Drug Abuse Training Grant T32 DA07232 (J.L.M.). We thank the Developmental Therapeutics Program at the National Cancer Institute/NIH for providing the M119 used in this study. We also thank Dr. Christopher Beck for his assistance and advice with the statistical analysis of our data.

Correspondence should be addressed to Dr. Jean M. Bidlack, Department of Pharmacology and Physiology, P.O. Box 711, University of Rochester, School of Medicine and Dentistry, 601 Elmwood Avenue, Rochester, NY 146428711. E-mail: jean_bidlack@urmc.rochester.edu.

J. L. Mathews' present address: Wegmans School of Pharmacy, St. John Fisher College, Rochester, NY 14618 D0I:10.1523/JNEUROSCI.2326-08.2008

Copyright $\odot 2008$ Society for Neuroscience $\quad$ 0270-6474/08/2812183-07\$15.00/0
Activation of PLC results in hydrolysis of phosphatidylinositol 4,5-bisphosphate to the two signaling molecules, inositol1,4,5-triphosphate, which mobilizes $\mathrm{Ca}^{2+}$ from intracellular stores, and diacylglycerol, which activates protein kinase $\mathrm{C}(\mathrm{PKC})$ (Rebecchi and Pentyala, 2000). PLC $\beta 2$ and PLC $\beta 3$ isoforms are activated by $\mathrm{G} \beta \gamma$ and are responsible for phosphatidylinositol (PI) hydrolysis stimulated by $\mathrm{G}_{\mathrm{i}}$-coupled receptors, with PLC $\beta 2$ being expressed primarily in hematopoietic cells (Rhee and Bae, 1997).

Previous data from our laboratories suggested that pharmacological inhibition of PLC $\beta 3$ might enhance opioid-induced antinociception (Xie et al., 1999). In these experiments with PLC $\beta 3$ knock-out mice, the mice lacking PLC $\beta 3$ had a 10 -fold potentiation in morphine-induced antinociception compared with control animals. This finding was one of the first indications that this pathway may be an important regulator of opioid signaling and subsequent analgesic responsiveness, and indicated that targeting PLC $\beta 3$ or PLC $\beta 3$ regulation pharmacologically could influence opioid efficacy.

Recently, we reported on a series of novel G $\beta \gamma$ inhibitors (Bonacci et al., 2006). From screening of a small molecule library, several compounds were found that bound to $\mathrm{G} \beta \gamma$ subunits and selectively inhibited $G \beta \gamma$ subunit signaling. The lead compound in the series, M119 (cyclohexanecarboxylic acid [2-(4,5,6- 


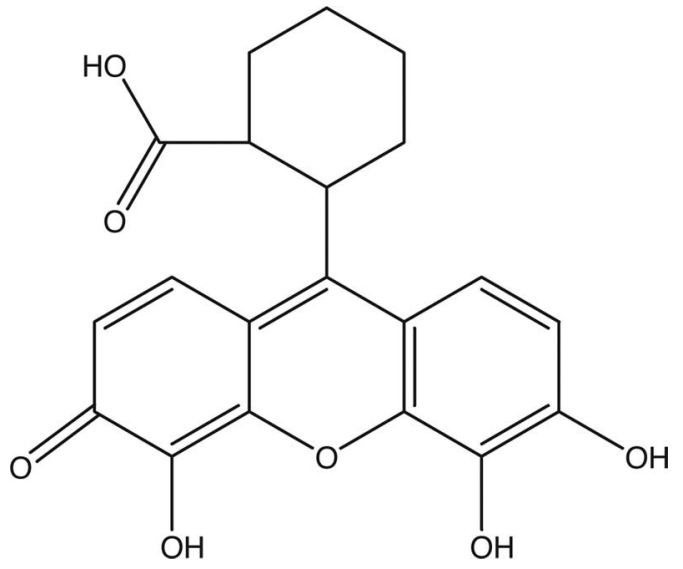

Figure 1. Chemical structure of the novel $G \beta \gamma$ inhibitor M119, which was obtained from the NCI diversity set (reference number NSC 119910).

trihydroxy-3-oxo-3H-xanthen-9-yl)-(9Cl)]), had high affinity for the G $\beta \gamma$ subunit and was an inhibitor of PLC $\beta 3$ signaling in vitro. In vivo, coadministration of M119 [100 nmol, intracerebroventricular (i.c.v.)] with graded doses of morphine (i.c.v.) resulted in a 10-fold leftward shift in the morphine antinociceptive dose-response curve (Bonacci et al., 2006), similar to the shift that had been seen with the PLC $\beta 3$ knock-out mice (Xie et al., 1999). Administration of M119 with morphine in the PLC $\beta 3$ knock-out mice had no additional effect (Bonacci et al., 2006), further supporting the hypothesis that the mechanism of action for M119 was through the attenuation of opioid-induced activation of PLC $\beta 3$ by G $\beta \gamma$. It is important to note that morphine still produced an analgesic response in the animals which had been administered M119, suggesting that regulation of other $\mathrm{G} \beta \gamma$ targets was still intact. This would be of particular importance in the activation of inwardly rectifying $\mathrm{K}^{+}$channels, which are mediated by $\mathrm{G} \beta \gamma$ and thought to play an important role in antinociception.

Selectively inhibiting downstream signaling from the $G \beta \gamma$ subunit, with a small molecule inhibitor, is a novel approach to targeting only a pathway of interest, while leaving the rest of the signaling machinery intact. The goal of this current study was to determine the effect M119 would have in vivo, not only on antinociception mediated by all three opioid receptors, but also in models of acute analgesic tolerance and dependence.

\section{Materials and Methods}

Animals. Male, ICR mice (20-30 g) (Harlan Industries) were housed in groups of five with food and water available ad libitum before any procedures. Animals were maintained on a $12 \mathrm{~h}$ light/dark cycle in a temperature-controlled animal colony. Studies were performed in accordance with the Policies on the Use of Animals in Neuroscience Research.

Chemicals. M119 (Fig. 1) was obtained from the chemical diversity set from the Developmental Therapeutics Program from the NCI/NIH. M119 is referenced as compound NSC 119910 within that series. M119 was used as directly supplied by NCI/NIH. Morphine sulfate was purchased from Mallinckrodt. [D-Ala ${ }^{2}, \mathrm{~N}-\mathrm{Me}-\mathrm{Phe}^{4}, \mathrm{Gly}^{5}$-ol]-enkephalin (DAMGO), [D-Pen $\left.{ }^{2}, \mathrm{D}-\mathrm{Pen}^{5}\right]$ enkephalin (DPDPE), [D-Ala $\left.{ }^{2}\right]-$ Deltorphin II (Deltorphin II), (trans)-3,4-dichloro- $N$-methyl- $N$-[2-(1pyrrolidinyl)-cyclohexyl]benzeneacetamide methane-sulfonate hydrate (U50,488), $\beta$-funaltrexamine ( $\beta$-FNA), and naloxone were purchased from Sigma.

Inositol phosphate assay using $h M O R-C H O, h K O R-C H O$, and $h D O R$ $\mathrm{CHO}$ cells. Chinese hamster ovary $(\mathrm{CHO})$ cells stably expressing the human $\kappa$ (hKOR-CHO), $\delta$ (hDOR-CHO) (L. Toll, Stanford Research Institute, Palo Alto, CA), or $\mu$ (hMOR-CHO) (G. Uhl, National Institute on Drug Abuse, Baltimore, MD) opioid receptor were used in the experiments. Cells in six-well plates were labeled by adding $4 \mu \mathrm{Ci}$ of $\left[{ }^{3} \mathrm{H}\right] \mathrm{i}-$ nositol for $24 \mathrm{~h}$ in inositol-free F-10 media, without serum. After labeling, $\mathrm{LiCl}$ was added directly to the labeling media at a final concentration of $10 \mathrm{~mm}$. Ligands or peptides were added at the same time. The final volume of each well was $1 \mathrm{ml}$. The plates were put back in to the incubator at $37^{\circ} \mathrm{C}$ for $30 \mathrm{~min}$, after which time the medium was aspirated and the plates were washed twice with PBS. Ice-cold $50 \mathrm{~mm}$ formic acid, $1 \mathrm{ml}$, was added to the plates which were placed in the cold room at $4^{\circ} \mathrm{C}$ for $30 \mathrm{~min}$. After the incubation, the contents of the plates were applied to Dowex AG1-X8 columns and allowed to flow all the way through the column. The columns were washed, twice each, with 50 and $100 \mathrm{~mm}$ formic acid, for a total of four washes, followed by elution of the inositol phosphate (IP)-containing fraction with $3 \mathrm{ml}$ of $1.2 \mathrm{M}$ ammonium formate $/ 0.1 \mathrm{M}$ formic acid. The eluted fraction was mixed with Scintisafe scintillation fluid (Fisher Scientific), for high salt, and counted. The data are represented as the fold increase over control in total inositol phosphates. All experiments were repeated three times and performed in duplicate. Control cells for each experiment were labeled with $\left[{ }^{3} \mathrm{H}\right]$ inositol and $\mathrm{LiCl}$, in the same manner as the treatment groups.

Drug solutions and injections. For i.c.v. injections, M119 was initially solubilized in DMSO and all subsequent dilutions were in distilled water. For systemic intraperitoneal (i.p.) injections, M119 was initially solubilized in a small volume of $\mathrm{NaOH}$ and brought to volume in $\mathrm{PBS}$ to $\mathrm{pH}$ 7.5. Vehicle was prepared in a similar manner without the drug. Additional compounds used in these studies were dissolved in the same vehicle as M119 for both i.c.v. and systemic injections. Intracerebroventricular injections were made directly into the lateral ventricle according to the modified method of Haley and McCormick (1957). The mouse was lightly anesthetized with ether, an incision was made in the scalp, and the injection was made $2 \mathrm{~mm}$ lateral and $2 \mathrm{~mm}$ caudal to bregma at a depth of $3 \mathrm{~mm}$ using a $10 \mu \mathrm{l}$ Hamilton syringe. The volume of all i.c.v. injections was $5 \mu$ l.

Antinociceptive testing. Antinociception was assessed using the $55^{\circ} \mathrm{C}$ warm-water tail-flick test. For the tail-flick test, the latency to the first sign of a rapid tail flick was taken as the behavioral endpoint (Jannsen et al., 1963). Each mouse was first tested for baseline latency by immersing its tail in the water and recording the time to response. Mice not responding within $5 \mathrm{~s}$ were excluded from further testing. Mice were then administered the test compound and tested for antinociception $20 \mathrm{~min}$ after the injection. A maximum score was assigned (100\%) to animals not responding within $15 \mathrm{~s}$ to avoid tissue damage. Antinociception was calculated by the following formula: $\%$ antinociception $=100 \times$ (test latency - control latency $) /(15$ - control latency $)$.

Effects of M119 + receptor-selective agonists. Mice were treated concomitantly with M119 (100 nmol, i.c.v.) and graded doses of receptor selective agonists (DAMGO, U50,488, DPDPE, and Deltorphin II). Control mice received a vehicle injection (i.c.v., $-20 \mathrm{~min}$ ). Antinociception was assessed $20 \mathrm{~min}$ after agonist injection. To test the effects of M119 systemically, mice received M119 (100 mg/kg, i.p.) followed immediately by graded doses of morphine subcutaneous (s.c.). Antinociception was tested 20 min after the agonist injection.

Acute antinociceptive tolerance. For quantitative measurements of acute opioid tolerance, a standardized state of tolerance was induced by administration of morphine at times $0,2 \mathrm{~h}, 4 \mathrm{~h}$, and $6 \mathrm{~h}$. The degree of tolerance was calculated from the shift in $\mathrm{ED}_{50}$ value from the nontolerant state to the tolerant condition (Way et al., 1969). All injections were i.c.v., and antinociception was assessed $20 \mathrm{~min}$ after each injection. Mice were lightly anesthetized before each injection. Previous reports have indicated that this dosing schedule induced acute morphine tolerance (Jiang et al., 1995). To assess the role of M119 in acute morphine tolerance, M119 and morphine were administered concomitantly at times 0, $2 \mathrm{~h}, 4 \mathrm{~h}$, and $6 \mathrm{~h}$. Time 0 is defined as the first injection of agonist.

Acute physical dependence. To assess development of acute morphine physical dependence (Yano and Takemori, 1977; Bilsky et al., 1996; Wang et al., 1999), mice were pretreated with a single injection of morphine ( $100 \mathrm{mg} / \mathrm{kg}$, s.c., $-4 \mathrm{~h}$ ). Before the administration of naloxone (30 $\mathrm{min})$, mice were injected with vehicle, i.c.v. Withdrawal was precipitated by an injection of the opioid antagonist, naloxone (10 mg/kg, i.p.). Mice 
were immediately placed in a clear cylinder and observed for $15 \mathrm{~min}$. The number of vertical jumps was recorded during this time. To test whether M119 affected morphine physical dependence, the same treatment as described above was used with M119 (100 nmol, i.c.v.) being administered $30 \mathrm{~min}$ before the administration of naloxone.

Receptor binding assays. The receptor binding assay was performed with membranes from hMOR-CHO cells using the $\mu$-selective radioligand $\left[{ }^{3} \mathrm{H}\right]$ DAMGO. Binding was performed in $50 \mathrm{~mm}$ Tris- $\mathrm{HCl}, \mathrm{pH} 7.5$, at $25^{\circ} \mathrm{C}$ for 60 min with varying concentrations of M119. Membrane protein $(50 \mu \mathrm{g}$ of hMOR-CHO) was incubated in $50 \mathrm{~mm}$ Tris- $\mathrm{HCl}, \mathrm{pH}$ $7.5 \mathrm{in}$ a final volume of $1 \mathrm{ml}$ with $0.25 \mathrm{~nm}\left[{ }^{3} \mathrm{H}\right]$ DAMGO and varying concentrations of M119. Nonspecific binding was determined in the presence of $10 \mu \mathrm{M}$ naloxone. After a $60 \mathrm{~min}$ incubation at $25^{\circ} \mathrm{C}$, the membranes were filtered onto No. 32 glass by vacuum filtration, followed by three washes with $3 \mathrm{ml}$ of ice-cold $50 \mathrm{~mm}$ Tris- $\mathrm{HCl}, \mathrm{pH} 7.5$. Samples were counted in $2 \mathrm{ml}$ of Scintsafe 30\% scintillation fluid.

cAMP assay. To measure cAMP, hMOR-CHO cells were grown in 12-well plates and incubated with $1 \mu \mathrm{M}$ forskolin, $100 \mu \mathrm{M}$ isobutylmethylxanthine (IBMX), and varying concentrations of M119, in serum-free DMEM media for $20 \mathrm{~min}$. After the incubation, the plates were immediately placed on ice and the cells were washed with PBS and lysed with $0.1 \mathrm{~N} \mathrm{HCl}$. cAMP was extracted and quantified, following the manufacturer's instructions, using the cAMP EIA direct assay kit from Assay Design. Data are represented as percentage of cAMP over control.

Statistical analysis. Data from dose-response experiments were fitted to a sigmoidal dose-response model using nonlinear regression analysis, and $\mathrm{ED}_{50}$ values and $95 \%$ confidence limits (CL) were calculated. A shift in the dose-response curve was determined from the $\mathrm{ED}_{50}$ values. To assess whether the $\mathrm{ED}_{50}$ or $\mathrm{IC}_{50}$ values for two dose-response or concentration-response curves were significantly different, an $F$ test was performed (GraphPad Prism 4.03). Values are reported as two-tailed $p$ values. Statistical significance was set at $p<0.05$. All data points are the mean of 7-10 mice, with SEM represented by error bars. Statistical analysis of the acute dependence data and inositol phosphate data used the Student's $t$ test.

\section{Results}

\section{The G $\beta \gamma$ inhibitor, M119, potentiated $\mu$-opioid} receptor-mediated antinociception

Previous data from our lab demonstrated that PLC $\beta 3$, a G $\beta \gamma$ subunit-regulated enzyme, was a negative modulator of $\mu$-opioid-dependent signaling (Xie et al., 1999). We therefore predicted that inhibiting $\beta \gamma$-dependent PLC $\beta 3$ activation would potentiate $\mu$-opioid-mediated antinociception, in a manner similar to the PLC $\beta 3$ knock-out studies (Xie et al., 1999; Bonacci et al., 2006). Previously, we observed that coadministration of M119 (Fig. 1) with morphine resulted in a significant $(p<$ $0.001), 10$-fold potentiation in morphine-mediated antinociception (Bonacci et al., 2006) (Fig. 2A). To determine whether the effects of M119 were specific to morphine, M119 was also administered with agonists selective for the $\mu, \kappa$, and $\delta$ receptors. Coadministration of M119 and the $\mu$-selective agonist, DAMGO, resulted in a sevenfold leftward shift in the DAMGO dose-response curve when compared with DAMGO alone $(p<0.001)$ (Fig. 2 B). DAMGO alone produced an $\mathrm{ED}_{50}$ value and $95 \% \mathrm{CL}$ of $0.07 \mathrm{nmol}(0.03-0.17 \mathrm{nmol})$, whereas DAMGO and M119 resulted in an $\mathrm{ED}_{50}$ value and 95\% CL of $0.01 \mathrm{nmol}$ (0.005-0.03 $\mathrm{nmol}$ ). A modest, twofold, shift was observed in the dose-response curve of the $\kappa$-selective agonist, U50,488, when administered with M119 ( $p<0.01$ ) (Fig. 3A). The $\mathrm{ED}_{50}$ values for U50,488 alone and U50,488 with M119 were $37 \mathrm{nmol}$ (29-47 $\mathrm{nmol})$ and $17 \mathrm{nmol}(9.4-31 \mathrm{nmol})$, respectively. M119 did not potentiate antinociception mediated through either $\delta_{1}$ or $\delta_{2}$ receptor. The $\mathrm{ED}_{50}$ values for the $\delta_{1}$-specific agonist, $\mathrm{DPDPE}$, alone or with M119 did not change significantly, 6.5 nmol (2.6-16 $\mathrm{nmol})$ and $5.4 \mathrm{nmol}(2.6-11 \mathrm{nmol})$, respectively (Fig. $3 B)$. The
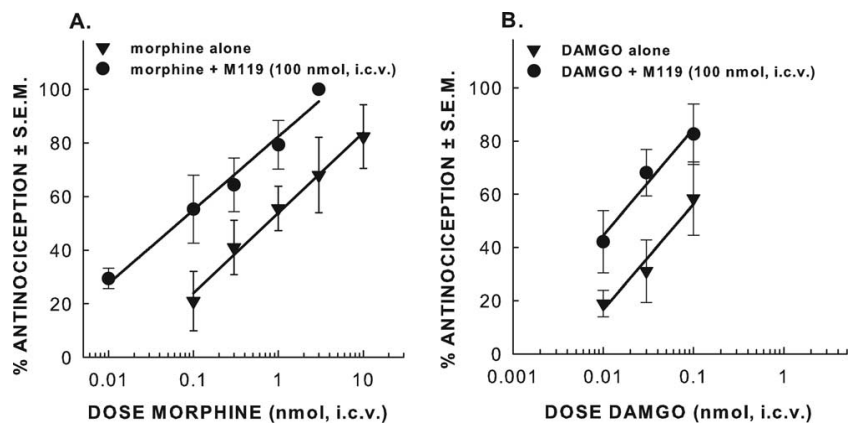

Figure 2. Effect of M119 on antinociception mediated by the $\mu$-opioid receptor. Coadministration of M119 (100 nmol, i.c.v.) with morphine (0.01-3 nmol, i.c.v.) resulted in a 10-fold potentiation of morphine-induced antinociception $(p<0.001)(\boldsymbol{A})$. The graph was reproduced with permission from Bonacci et al. (2006), their Figure 4. Concomitant administration of M119 (100 nmol) with the $\mu$-selective agonist, DAMGO $(0.01-0.1 \mathrm{nmol})$, resulted in a sevenfold leftward shift in $\mathrm{ED}_{50}$ value compared with DAMG0 alone $(p<0.001)(\boldsymbol{B})$. All data points are the mean of 7-10 mice, with SEM represented by error bars. Antinociception was assessed $20 \mathrm{~min}$ after agonist and $\mathrm{M} 119$ injection in the $55^{\circ} \mathrm{C}$ warm-water tail-flick test.

$\delta_{2}$-selective agonist, Deltorphin II, produced an $\mathrm{ED}_{50}$ value of 11 nmol (5.5-23 nmol) which was unchanged in the presence of M119, $11 \mathrm{nmol}$ (5.1-23 nmol) (Fig. 3C). Administration of M119 alone had no effect on baseline tail-withdrawal latencies (Bonacci et al., 2006). These experiments demonstrated that M119 selectively potentiated $\mu$-opioid-dependent antinociception.

To determine whether M119 would be effective after systemic administration, M119 was administered i.p. followed immediately with a s.c. injection of morphine. Systemic administration of morphine alone produced an $\mathrm{ED}_{50}$ value of $5.0 \mathrm{mg} / \mathrm{kg}(2.9-8.4$ $\mathrm{mg} / \mathrm{kg}$ ), which was shifted fourfold to the left in the presence of M119, producing an $\mathrm{ED}_{50}$ value of $1.3 \mathrm{mg} / \mathrm{kg}(0.59-2.8 \mathrm{mg} / \mathrm{kg})$ $(p<0.001)$ (Fig. 4).

\section{M119 inhibition of IP production mediated by the $\boldsymbol{\mu}$-opioid receptor}

We previously proposed that the potentiation in morphineinduced antinociception was caused by M119 inhibition of $\beta \gamma$ dependent PLC $\beta 3$ (Bonacci et al., 2006). To demonstrate that M119 blocked $\mu$-opioid receptor-dependent PLC activation, we measured morphine- and DAMGO-dependent total inositol phosphate (IP) production in hMOR-CHO cells. Both DAMGO $(10 \mu \mathrm{M})$ and morphine $(10 \mu \mathrm{M})$ significantly increased total IP measured compared with control, with a fourfold and threefold increase, respectively $(p<0.01)$ (Fig. $5 A$ ). This increase was significantly attenuated with the addition of the $\beta \gamma$ inhibitor, M119 $(10 \mu \mathrm{M})(p<0.05)$, whereas M119 had no effect by itself. The $\mu$-selective antagonist, $\beta$-FNA also attenuated DAMGOand morphine-dependent IP production (Fig. $5 A)(p<0.05)$. The effect of M119 on DAMGO-stimulated IP generation was concentration dependent (Fig. 5B). Maximal M119 effects were observed at $10 \mu \mathrm{M}(p<0.05)$ and $30 \mu \mathrm{M}(p<0.01)$. The $\kappa$-selective agonist, U50,488 $(10 \mu \mathrm{M})$ and the $\delta$-selective agonists, DPDPE $(10 \mu \mathrm{M})$ had no effect on IP production alone or in the presence of M119 in the hMOR-CHO cells (data not shown). These data demonstrate that the $\mu$-opioid receptor can stimulate PLC activation and that this coupling was blocked by M119.

To determine whether other opioid receptors couple to PLC activation, we examined opioid receptor-dependent IP generation in hDOR-CHO and hKOR-CHO cells. In the hDOR-CHO cells neither DPDPE $(10 \mu \mathrm{M})$ or Deltorphin II $(10 \mu \mathrm{M})$ significantly increased IP generation over control treated cells (Fig. 5C). 
A.

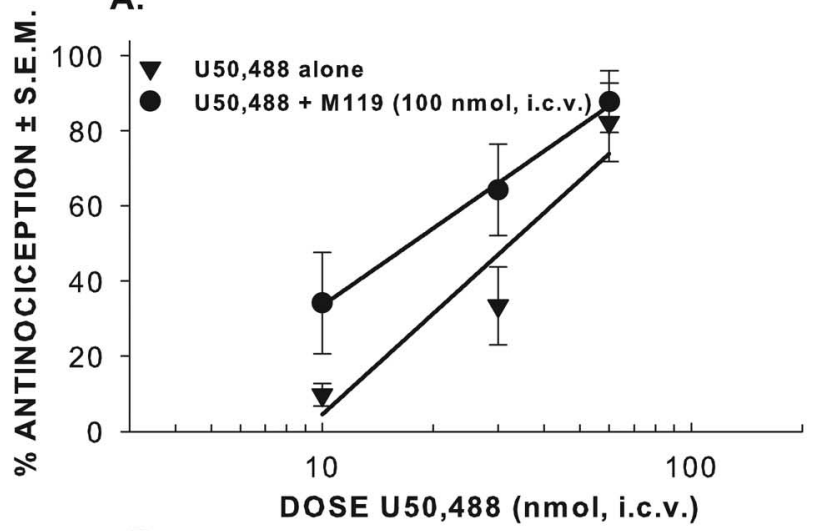

B.

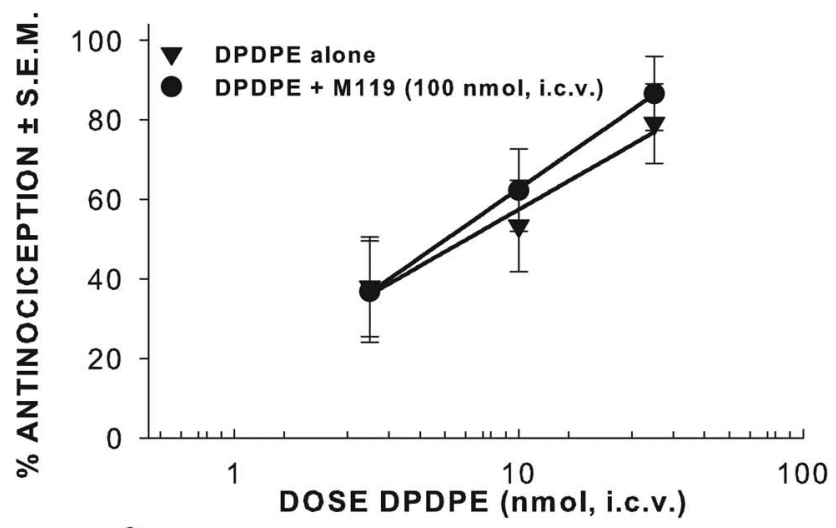

C.

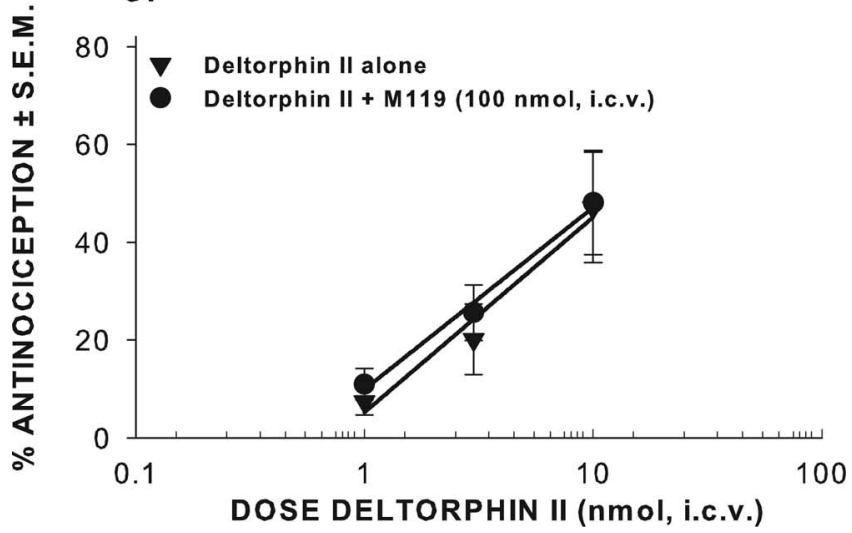

Figure 3. Effect of M119 on antinociception mediated by the $\kappa$ - and $\delta$-opioid receptors. A moderate, twofold, leftward shift in $\mathrm{ED}_{50}$ value was observed with coadministration of M119 (100 nmol, i.c.v.) and the $\kappa$-selective, agonist, U50,488 (10 - $60 \mathrm{nmol}$, i.c.v.) compared with U50,488 alone $(p<0.01)(\boldsymbol{A})$. Coadministration of M119 with either the $\delta_{1}$-selective agonist, DPDPE (3-30 nmol, i.c.v.) (B) or the $\delta_{2}$-selective agonist, Deltorphin II (1-10 nmol, i.c.v.) (C), did not result in a shift of the $E_{50}$ value compared with either agonist alone. Antinociception was assessed $20 \mathrm{~min}$ after agonist and $\mathrm{M} 119$ injection in the $55^{\circ} \mathrm{C}$ tail-flick test. All data points are the mean of 7-10 mice, with SEM represented by error bars.

Treatment with M119 (10 $\mu \mathrm{M})$ and the $\delta$-selective antagonist, naltrindole $(100 \mu \mathrm{M})$ also had no significant effect (Fig. $5 C$ ). Treatment with U50,488 (10 $\mu \mathrm{M})$, with or without M119 $(10 \mu \mathrm{M})$ or nor-BNI $(10 \mu \mathrm{M})$, the $\kappa$-selective antagonist, in the hKOR$\mathrm{CHO}$ cells had no significant effect on IP production over control treated cells (Fig. 5D). Importantly, the levels of opioid receptors were the same for all three cell lines $\left(B_{\max }\right.$ values not significantly different, data not shown). These in vitro data correlate with the effects of M119 in vivo, where only in the mice treated with the $\mu$-preferring compounds was a significant potentiation in an-

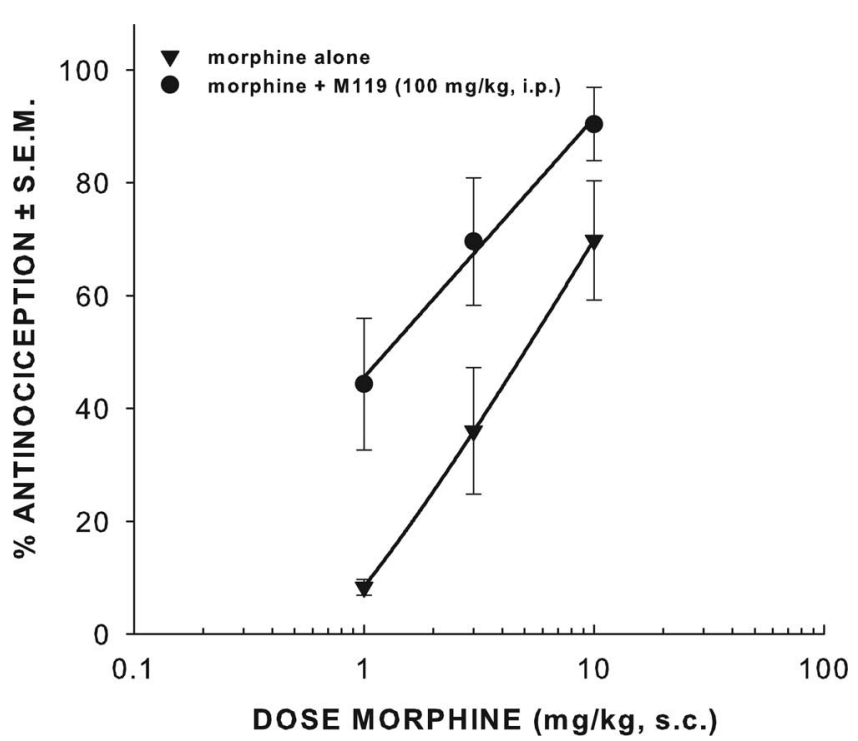

Figure 4. Effect of systemic administration of M119 on morphine-induced antinociception. Systemic administration of $M 119$ (100 mg/kg, i.p.) with graded doses of morphine (1-10 mg/ $\mathrm{kg}$, s.c.) resulted in a potentiation of antinociception as measured by a fourfold leftward shift in the $\mathrm{ED}_{50}$ value compared with morphine alone $(p<0.01)$. All data points are the mean of 7-10 mice, with SEM represented by error bars. Antinociception was assessed $20 \mathrm{~min}$ after agonist injection in the $55^{\circ} \mathrm{C}$ warm-water tail-flick test.

tinociception observed. It is possible that the selective effects of M119 observed in vivo on $\mu$-opioid receptor-dependent antinociception are the result of selective coupling of $\mu$-opioid receptor to $\mathrm{G} \beta \gamma$-dependent PLC activation.

Effect of M119 on acute morphine antinociceptive tolerance As an initial test of the efficacy of M119 in reducing the development of morphine antinociceptive tolerance, an acute tolerance assay was performed. We used this assay to measure tolerance because it requires considerably less compound than traditional tolerance paradigms, while still yielding reliable results. The antinociceptive effect of repeated $(0,2,4,6 \mathrm{~h})$ doses (1-10 nmol) of morphine and the development of acute antinociceptive tolerance are shown in Figure 6A. Morphine produced dosedependent antinociception in the $55^{\circ} \mathrm{C}$ warm-water tail-flick assay. The $\mathrm{ED}_{50}$ value $(95 \% \mathrm{CL})$ for i.c.v. morphine at time 0 was $0.59 \mathrm{nmol}(0.16-2.2 \mathrm{nmol})$. After repeated administration, acute morphine antinociceptive tolerance developed by $4 \mathrm{~h}$ with a significant shift in the $\mathrm{ED}_{50}$ value $(p<0.01)$. At $4 \mathrm{~h}$, the $\mathrm{ED}_{50}$ value had shifted eightfold, $4.9 \mathrm{nmol}(1.8-13 \mathrm{nmol})$ and by $6 \mathrm{~h}$, the $\mathrm{ED}_{50}$ value had shifted 16-fold, $9.6 \mathrm{nmol}(3.2-29 \mathrm{nmol})(p<$ $0.001)$. Coadministration of M119 with morphine greatly attenuated acute morphine antinociceptive tolerance (Fig. 6B). The $\mathrm{ED}_{50}$ values remained virtually unchanged, with no statistical difference, from time $0,0.16 \mathrm{nmol}(0.02-1.3 \mathrm{nmol})$ to the $6 \mathrm{~h}$ time point, $0.22 \mathrm{nmol}(0.008-5.7 \mathrm{nmol})$. Control mice were treated under the same injection protocol, however, received only vehicle. No significant change from baseline tail-withdrawal values were observed for any of the control mice at any of the times tested (data not shown), indicating that the procedure used in the acute tolerance protocol was not contributing to the data which was observed.

\section{Effect of M119 on acute morphine physical dependence}

In an acute model of morphine dependence, mice were treated with morphine (100 mg/kg, s.c., -4 h), followed by M119 (100 
A.

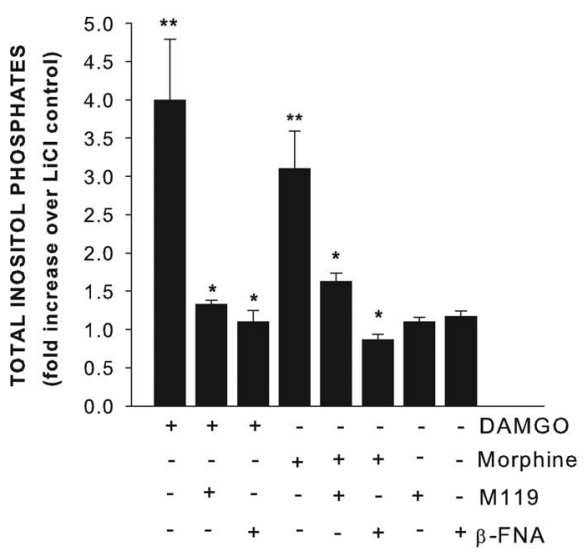

B.

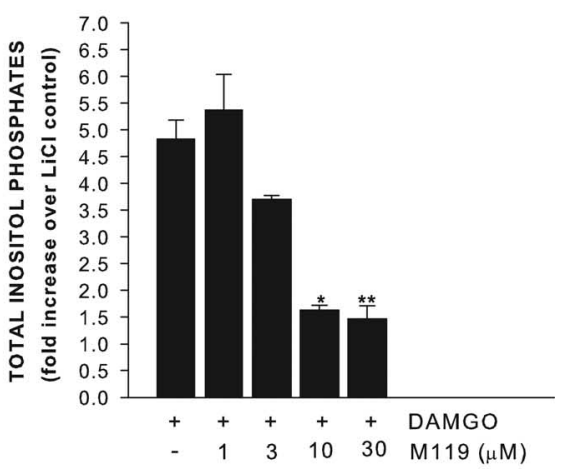

c.

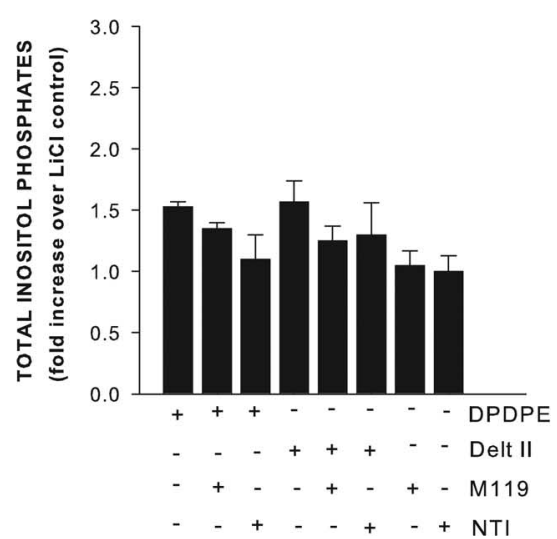

Figure 5. The effects of $\mu$-, $\delta$-, and $\kappa$-selective opioid agonists and M119 on IP production in $\mathrm{CHO}$ cells stably expressing one of the human opioid receptors. IP levels were measured as described in Materials and Methods. The $\mu$ agonists, DAMGO (10 $\mu \mathrm{M})$ and morphine $(10 \mu \mathrm{M})$, both significantly increased the total inositol phosphates measured in hMOR-CHO cells $\left(^{* *} p<0.01\right)$ compared with control $(\boldsymbol{A})$. The $\mu$-selective antagonist $\beta$-FNA $(10 \mu \mathrm{M})$ attenuated this response $\left({ }^{*} p<0.05\right)$ compared with the agonist alone. M119 inhibition of DAMG0-stimulated IP generation was concentration dependent [10 $\mu \mathrm{M}\left({ }^{*} p<0.05\right)$ and $30 \mu \mathrm{M}$ $\left({ }^{* *} p<0.01\right)$, compared with DAMG0 alone] (B). In the hDOR-CHO cells, neither $\delta$-selective agonist, DPDPE (10 $\left.\mu \mathrm{M}\right)$ nor Deltorphin II $(10 \mu \mathrm{M})$ significantly increased IP generation over control treated cells (C). M119 and naltrindole (NTI) also had no effect in the hDOR-CHO cells. The $\kappa$-selective agonist, U50,488 (10 $\mu \mathrm{M})$, had no significant effect on IP generation with or without M119 $(10 \mu \mathrm{m})$ or nor-BNI $(10 \mu \mathrm{m})$ in the hKOR-CHO cells $(\boldsymbol{D})$.

$\mathrm{nmol}$, i.c.v.) or vehicle (i.c.v.) $30 \mathrm{~min}$ before naloxone $(10 \mathrm{mg} / \mathrm{kg}$, i.p.), which resulted in withdrawal jumping. Control mice jumped an average of $71 \pm 12$ times in the 15 min counting period (Fig. 7). Mice treated with M119 jumped significantly less times in the 15 min counting period, an average of $23 \pm 14$ compared with $71 \pm 12$ for the control mice (Fig. 7). Post hoc analysis (Student's $t$ test) indicated that coadministration of M119 30 min before naloxone administration produced significantly less vertical jumps than vehicle administration before naloxone $(p<0.05)$.

\section{Effects of M119 on opioid receptor binding and downstream signaling}

It was important to demonstrate that increasing concentrations of M119 did not inhibit the ability of an opioid agonist to bind the receptor. Receptor binding assays were performed to address whether M119 mediated its effects through direct binding and activation of the opioid receptors. Increasing concentrations of M119 were incubated with the $\mu$-selective peptide $\left[{ }^{3} \mathrm{H}\right]$ DAMGO in membranes from hMOR-CHO cells. M119 did not signifi- cantly inhibit $\left[{ }^{3} \mathrm{H}\right]$ DAMGO binding to the $\mu$-opioid receptor at any concentration tested (Fig. $8 \mathrm{~A}$ ).

It is well established that all three types of opioid receptors activate $\mathrm{G}_{\mathrm{i}}$, resulting in inhibition of adenylyl cyclase activity (Sharma et al., 1977; Childers, 1991). Therefore, if the receptor is in fact signaling effectively, this would be reflected as an inhibition of cAMP levels. Previous in vitro studies with M119 had suggested that the compound did not prevent the heterotrimeric G-protein from reassembling (Bonacci et al., 2006). However, it was unclear whether M119 would potentiate the downstream opioid effects on cAMP. hMOR-CHO cells were treated with forskolin and IBMX to stimulate cAMP production. The $\mu$-selective agonist, DAMGO, concentration-dependently inhibited cAMP levels with an $\mathrm{IC}_{50}$ value of $24 \pm 3.6 \mathrm{~nm}$ (Fig. 8 B). Concomitant treatment of cells with DAMGO and M119 (10 $\mu \mathrm{M}$ ) did not potentiate this effect as shown by the $\mathrm{IC}_{50}$ value of $26 \pm 2.9 \mathrm{~nm}$ (Fig. $8 \mathrm{~B}$ ). A similar effect was observed with morphine (data not shown). The general opioid antagonist, naloxone, reversed the effects of both DAMGO and morphine indicating that both agonists were inhibiting cAMP production through an opioidmediated pathway (data not shown).

\section{Discussion}

In the current study, our laboratory took the novel approach of using a $G \beta \gamma$ inhibitor to influence the efficacy and potency of morphine in several animal models of $\mu$-opioid receptor function. Our fundamental hypothesis for the mechanism of action of this compound is based on studies conducted by Xie et al. (1999) demonstrating that the $\mathrm{G} \beta \gamma$-dependent enzyme, PLC $\beta 3$, was a negative modulator of $\mu$-opioid receptor signaling both in PLC $\beta 3$ knock-out mice and in dorsal root ganglion neurons. We demonstrated previously that the G $\beta \gamma$ inhibitor, M119, inhibited the activation of PLC $\beta 3$ by $\mathrm{G} \beta \gamma$ in vitro and that concomitant administration of this novel compound with morphine in vivo resulted in a 10-fold shift in morphine analgesic potency, virtually identical, to data from the PLC $\beta 3$ knock-out studies (Xie et al., 1999; Bonacci et al., 2006). In addition, M119 had no effect in PLC $\beta 3$ knock-out mice, further supporting in vitro evidence that M119 was blocking the binding of G $\beta \gamma$ to PLC $\beta 3$ (Bonacci et al., 2006).

Here, we explored further the specificity and underlying mechanisms of action of M119 in potentiating analgesia as well as presented evidence extending the potential therapeutic efficacy of this approach.

\section{M119 displayed $\mu$-opioid receptor selectivity in vivo}

Increased analgesic potency was observed in mice treated with M119 and morphine and also M119 and the receptor-selective agonist, DAMGO. Minimal effects were observed with $\kappa$ - and 
A.

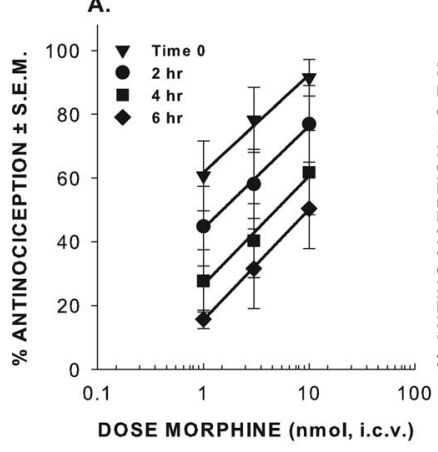

Figure 6. Effect of M119 on acute morphine antinociceptive tolerance. In an acute model of morphine antinociceptive tolerance, morphine was administered at times $0,2,4,6 \mathrm{~h}(\boldsymbol{A})$. At $4 \mathrm{~h}$, significant tolerance $(p<0.01)$ had developed as measured by an eightfold shift in the $\mathrm{ED}_{50}$ value and by $6 \mathrm{~h}$, a 16 -fold shift in the $\mathrm{ED}_{50}$ value was measured $(p<0.001)$. Concomitant administration of M119 (100 nmol, i.c.v.) and graded doses of morphine attenuated acute morphine antinociceptive tolerance at all time points tested $(\boldsymbol{B})$. Both compounds were administered at times $0,2,4,6 \mathrm{~h}$. No significant change in the $\mathrm{ED}_{50}$ values was determined. Antinociception was assessed $20 \mathrm{~min}$ after each injection in the $55^{\circ} \mathrm{C}$ tail-flick test. Control mice had no change from baseline tail-withdrawal latencies at any of the time points tested (data not shown).

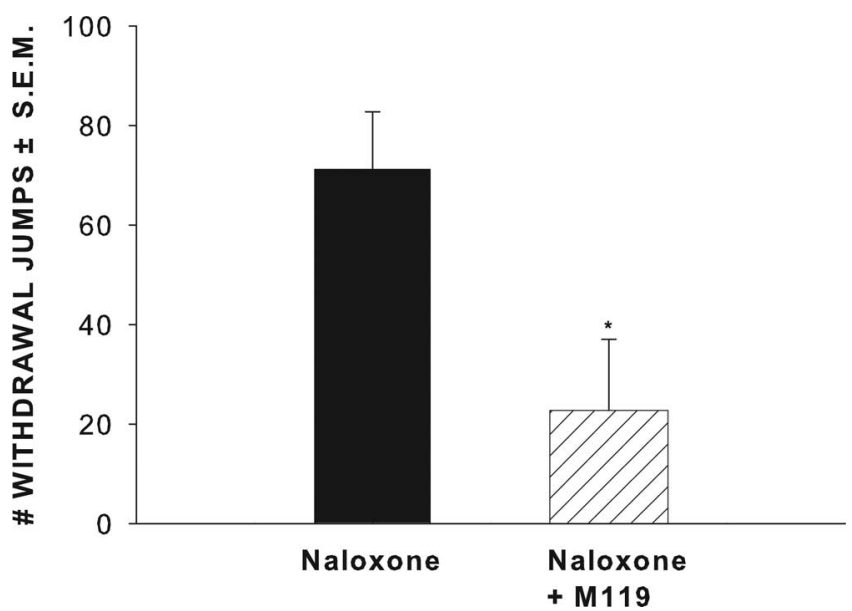

Figure 7. Effect of M119 on morphine-induced physical dependence. In a measure of acute morphine dependence, mice were administered morphine (100 mg/kg, s.c., $-4 \mathrm{~h}$ ) and withdrawal was precipitated by injection of naloxone $(10 \mathrm{mg} / \mathrm{kg}$, i.p.). Withdrawal jumping was counted for $15 \mathrm{~min}$ after antagonist injection. Injection of M119 (100 nmol, i.c.v.) $30 \mathrm{~min}$ before the injection of naloxone resulted in significantly less vertical jumps than naloxone alone ${ }^{*} p<$ 0.05).

$\delta$-selective agonists, U50,488, DPDPE, and Deltorphin II. These studies indicated that M119 was selective, in vivo, for the potentiation of $\mu$-mediated analgesia. Similar results were obtained from the in vitro IP assay, with only the $\mu$ agonists, DAMGO and morphine, stimulating IP generation which was inhibited by M119. We propose that the $\kappa$ - and $\delta$-opioid receptors do not activate the same PLC isoforms, or are not acting in the same brain regions, and therefore are not inhibited by the same PLCdependent feedback pathway observed for the $\mu$-opioid receptor and it is for this reason that that M119 lacks efficacy with these receptors. Why three receptors that couple to the same Gi protein have differential effects on PLC activation is unclear and will require further investigation.

Galeotti et al. (2006) recently demonstrated the importance of PLC $\beta 3$ in opposing morphine analgesia using antisense phosphodiester oligonucleotides specifically to PLC $\beta 3$. In mice
A.

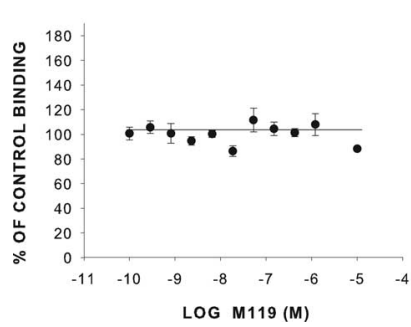

B.

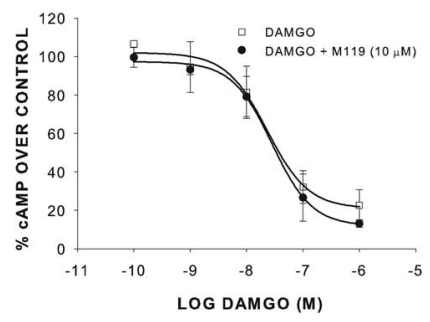

Figure 8. Effect of M119 on $\left[{ }^{3} \mathrm{H}\right] \mathrm{DAMGO}$ binding to the $\mu$-opioid receptor $(\boldsymbol{A})$ and on DAMG0-induced inhibition of cAMP levels $(\boldsymbol{B})$. hMOR-CHO membranes were incubated with $0.25 \mathrm{nM}\left[{ }^{3} \mathrm{H}\right] \mathrm{DAMG} 0$ and varying concentrations of M119 as described in Materials and Methods. M119 did not significantly inhibit [ $\left.{ }^{3} \mathrm{H}\right] \mathrm{DAMGO}$ binding to the hMOR (A). DAMGO inhibited forskolin-stimulated CAMP production and this effect was not potentiated by the addition of the $\beta \gamma$ inhibitor, M119 (B). hMOR-CHO cells were treated with varying concentrations of DAMGO along with $10 \mu \mathrm{m}$ forskolin and $100 \mathrm{~mm}$ IBMX, with and without $10 \mu \mathrm{M}$ M119. DAMG0 dosedependently inhibited CAMP $\left(\mathrm{IC}_{50}=24 \pm 3.6 \mathrm{nM}\right)$, and concomitant treatment of cells with DAMG0 and $10 \mu \mathrm{M} M 119$ did not potentiate this effect $\left(\mathrm{IC}_{50}=26 \pm 2.9 \mathrm{~nm}\right)$.

treated both with morphine and the antisense oligonucleotide, a potentiation in analgesic response was observed (Galeotti et al., 2006). The same group also demonstrated localization of PLC $\beta 3$ in regions of the brain important for nociceptive transmission which have been previously shown to also express the $\mu$-opioid receptor (Galeotti et al., 2006).

\section{Downstream signaling and the role of phospholipids in tolerance and dependence}

There is evidence that the PLC pathway can influence the development of opioid tolerance and dependence. Inhibitors of PLC (Smith et al., 1999), $\mathrm{IP}_{3}$ receptors (Smith et al., 1999), and PKC (Bilsky et al., 1996; Smith et al., 1999; Bohn et al., 2002) all attenuated morphine tolerance. PKC knock-out animals also exhibited attenuated morphine tolerance (Zeitz et al., 2001). It has also been suggested that generation of $\mathrm{IP}_{3}$ and DAG along with activation of PKC may be important for the development of opioid dependence (Fundytus and Coderre, 1996; Smith et al., 1999). In the current studies, M119 attenuated both acute antinociceptive tolerance and dependence, but which of these specific mechanisms downstream of $\beta \gamma$-dependent PLC $\beta 3$ regulation are responsible for these effects remains to be defined. Additionally, it will be important to study the effect of M119 on chronic morphine-antinociceptive tolerance and dependence.

\section{Specificity and underlying mechanisms of action of M119 in vitro}

Previous studies from our lab tested the effects of differentially targeting G $\beta \gamma$ signaling in intact cells. M119 was shown to inhibit activation of phosphoinositide 3 kinase $\gamma(\mathrm{PI} 3 \mathrm{~K} \gamma)$ and fMLPinduced $\mathrm{Ca}^{2+}$ increases in differentiated HL-60 leukocytes (Bonacci et al., 2006). The fMLP receptor couples to Gi in the HL-60 cells. Importantly, M119 had no effect on carbacholdependent increases in $\mathrm{Ca}^{2+}$ in HEK293 cells stably expressing the Gq-linked M3-muscarinic receptor, confirming a specific effect of M119 on G $\beta \gamma$-dependent $\mathrm{Ca}^{2+}$ mobilization (Bonacci et al., 2006). These data suggest that M119 was in fact penetrating into the cell to produce an effect through a $\beta \gamma$-mediated mechanism. Our current studies demonstrated that M119 did not inhibit $\left[{ }^{3} \mathrm{H}\right] \mathrm{DAMGO}$ binding to the $\mu$-opioid receptor at any concentration tested. As a means to address whether the receptor was signaling as expected, we performed a cAMP assay. The $\mathrm{IC}_{50}$ value for DAMGO was not significantly changed in the presence 
of M119. Additionally, M119 produced a concentrationdependent inhibition of IP generation in hMOR-CHO cells treated with either DAMGO or morphine.

In conclusion, we demonstrated that selectively inhibiting $\mathrm{G} \beta \gamma$ signaling represents a novel approach to target only the effector of interest, in this case, PLC $\beta 3$, while leaving other signaling pathways intact. This approach represents a novel strategy for potentiating opioid efficacy and also attenuating morphine tolerance and dependence.

\section{References}

Bilsky EJ, Bernstein RN, Wang Z, Sadée W, Porreca F (1996) Effects of naloxone and D-Phe-Cys-Tyr-D-Trp-Arg-Thr-Pen-Thr- $\mathrm{NH}_{2}$ and the protein kinase inhibitors $\mathrm{H} 7$ and $\mathrm{H} 8$ on acute morphine dependence and antinociceptive tolerance in mice. J Pharmacol Exp Ther 277:484-490.

Bohn LM, Lefkowitz RJ, Caron MG (2002) Differential mechanisms of morphine antinociceptive tolerance revealed in $\beta$ arrestin-2-knock-out mice. J Neurosci 22:10494-10500.

Bonacci TM, Mathews JL, Yuan C, Lehmann DM, Malik S, Wu D, Font JL, Bidlack JM, Smrcka AV (2006) Differential targeting of G $\beta \gamma$-subunit signaling with small molecules. Science 312:443-446.

Childers SR (1991) Opioid receptor-coupled second messenger systems. Life Sci 48:1991-2003.

Fundytus ME, Coderre TJ (1996) Chronic inhibition of intracellular $\mathrm{Ca}^{2+}$ release or protein kinase $\mathrm{C}$ activation significantly reduces the development of morphine dependence. Eur J Pharmacol 300:173-181.

Galeotti N, Stefano GB, Guarna M, Bianchi E, Ghelardini C (2006) Signaling pathway of morphine induced acute thermal hyperalgesia in mice. Pain 123:294-305.

Haley TJ, McCormick WG (1957) Pharmacological effects produced by intracerebral injection of drugs in the conscious mouse. $\mathrm{Br} \mathrm{J}$ Pharmacol Chemother 12:12-15.

Jannsen PA, Niemegeers CJ, Dorg JG (1963) The inhibitory effect of fentanyl and other morphine-like analgesics on the warm water induced tail withdrawal reflex in rats. Arzneim-Forsch 13:502-507.

Jiang Q, Seyed-Mozaffari A, Sebastian A, Archer S, Bidlack JM (1995) Preventing morphine antinociceptive tolerance by irreversible mu opioid antagonists before the onset of their antagonism. J Pharmacol Exp Ther 273:680-688

Law PY, Loh HH, Wei LN (2004) Insights into the receptor transcription and signaling: implications in opioid tolerance and dependence. Neuropharmacology 47:300-311.

Moises HC, Rusin KI, Macdonald RL (1994) $\mu$ - and $\kappa$-opioid receptors selectively reduce the same transient components of high-threshold calcium current in rat dorsal root ganglion sensory neurons. J Neurosci 14:5903-5916.

North RA, Williams JT, Surprenant A, Christie MJ (1987) Mu and delta receptors belong to a family of receptors that are coupled to potassium channels. Proc Natl Acad Sci U S A 84:5487-5491.

Rebecchi MJ, Pentyala SN (2000) Structure, function, and control of phosphoinositide-specific phospholipase C. Physiol Rev 80:1291-1335.

Rhee SG, Bae YS (1997) Regulation of phosphoinositide-specific phospholipase C isozymes. J Biol Chem 272:15045-15048.

Sharma SK, Klee WA, Nirenberg M (1977) Opiate-dependent modulation of adenylate cyclase. Proc Natl Acad Sci U S A 74:3365-3369.

Smith FL, Lohmann AB, Dewey WL (1999) Involvement of phospholipid signal transduction pathways in morphine tolerance in mice. Br J Pharmacol 128:220-226.

Wang Z, Bilsky EJ, Wang D, Porreca F, Sadée W (1999) 3-Isobutylmethylxanthine inhibits basal mu-opioid receptor phosphorylation and reverses acute morphine tolerance and dependence in mice. Eur J Pharmacol 371:1-9.

Way EL, Loh HH, Shen FH (1969) Simultaneous quantitative assessment of morphine tolerance and physical dependence. J Pharmacol Exp Ther 167:1-8.

Xie W, Samoriski GM, McLaughlin JP, Romoser VA, Smrcka A, Hinkle PM, Bidlack JM, Gross RA, Jiang H, Wu D (1999) Genetic alteration of phospholipase $C \beta 3$ expression modulates behavioral and cellular responses to $\mu$ opioids. Proc Natl Acad Sci U S A 96:10385-10390.

Yano I, Takemori AE (1977) Inhibition by naloxone of tolerance and dependence in mice treated acutely and chronically with morphine. Res Commun Chem Pathol Pharmacol 16:721-734.

Zeitz KP, Malmberg AB, Gilbert H, Basbaum AI (2001) Reduced development of tolerance to the analgesic effects of morphine and clonidine in PKC gamma mutant mice. Pain 94:245-253. 